\title{
Health-Benefit Assets of Different Indian Processed Teas: A Comparative Approach
}

\author{
Anjan Hazra1,2, Jhinuk Saha1, Nirjhar Dasgupta1, Chandan Sengupta², \\ Padmanabhan Mohan Kumar ${ }^{3}$, Sauren Das ${ }^{*}$ \\ ${ }^{1}$ Agricultural and Ecological Research Unit, Indian Statistical Institute, Kolkata, India \\ ${ }^{2}$ Department of Botany, University of Kalyani, Kalyani, India \\ ${ }^{3}$ Tea Board of India, National Tea Research Foundation, Kolkata, India \\ Email: *sauren@isical.ac.in
}

How to cite this paper: Hazra, A., Saha, J., Dasgupta, N., Sengupta, C., Kumar, P.M. and Das, S. (2017) Health-Benefit Assets of Different Indian Processed Teas: A Comparative Approach. American Journal of Plant Sciences, 8, 1607-1623.

https://doi.org/10.4236/ajps.2017.87111

Received: April 26, 2017

Accepted: June 19, 2017

Published: June 23, 2017

Copyright $\odot 2017$ by authors and Scientific Research Publishing Inc. This work is licensed under the Creative Commons Attribution International License (CC BY 4.0).

http://creativecommons.org/licenses/by/4.0/

\begin{abstract}
A comparative deliberation has been considered among three Indian processed teas (black, green and white) in respect to their prevalence of some secondary metabolites, antioxidant ability (ABTS and DPPH assay), nutritional properties, inorganic elemental profile and bactericidal efficiency. Green and white tea, incidence of total phenol, total flavonoids, proanthocyanidins and tannin are higher than the black. ABTS and DPPH study reveals lower $\mathrm{IC}_{50}$ occurred in Green tea. Green tea is enriched in $\mathrm{Na}, \mathrm{Fe}, \mathrm{Mg}$, and $\mathrm{Mn}$ content; black is rich in $\mathrm{K}, \mathrm{Ca}$ and white has highest $\mathrm{Zn}$. Total sugar and free amino acid are highest in white tea; total protein content is almost same in all three types. Green tea is enriched with vitamin C. Antimicrobial asset is experienced against Bacillus subtilis, Staphylococcus aureus (gram $+\mathrm{ve)}$ and Escherichia coli and Pseudomonas aeruginosa (gram - ve) bacteria. Study revealed that green tea has higher antimicrobial activity than the other two, though higher inhibitory effect of black tea might be attributed to the presence of substantial amount of tannin. Statistical evaluation reflects that in all organic and aqueous extracts, secondary metabolites correlate linearly with DPPH and ABTS assays but are not consistent with bactericidal efficiency in all cases.
\end{abstract}

\section{Keywords}

Antioxidant, Bactericidal Properties, Dietary Assessment, Minerals, Secondary Metabolites, Tea

\section{Introduction}

Tea is the largest consumed beverage across the globe and being considered as the second most widely consumed drink after water [1] [2]. In proper sense, tea refers to the infusion prepared from leaves of the tea plant, Camellia sinensis (L.) 
Kuntze, an evergreen flowering tree, belonging to the family Theaceae, native to the mountainous regions of south-western China and neighbouring countries [3] [4] [5]. The two main commercial varieties are small-leafed $C$. sinensis var. sinensis, adapted to cool weather and high altitude, and large-leafed $C$. sinensis var. assamica (J. W. Mast.) Kitam., which grows well in tropical and sub-tropical environments. Tea leaves contain a high concentration of phytochemicals including polyphenolic catechin and the methylxanthine caffeine. Different varieties of teas are being consumed according to their preferential taste of the end users. Basically, use of black tea has worldwide acceptability, while green tea is mostly popular in the countries of South-Asia and North Africa. Popularity of white tea is being increased to the consumers from Western World, mostly for its taste and difference in their processing technique from the other types [6]. Rudimentary or unopened leaf buds [7], in which chlorophyll formation is much less or nil and is not withered, rolled, or crushed like black and green teas, but steamed rapidly and air-dried [6]. Heat treated Green tea rolled and dried, thus, endogenous polyphenol oxidase is disengaged. Black tea is prepared by crushing withered tea leaves and thus enzyme-mediated oxidation of tea leaf occurred, some oligomers formed, such as theaflavins, and polymers known as thearubigins [8].

Recently, beside the aromatic preferences of tea, the health benefit influence has also become attentive to the health-conscious people. Though from the ancient era (more than 4000 years) medicinal importance of tea was judged well, recent scientific data have proved much that tea is a potential food supplement for antioxidant as well as an effective chemo-protectant agent for toxic substances and carcinogens [9]. According to Sajilata et al. [8] different polyphenol (flavonols, caffeine, phenolic acids, theanine etc.) contents of green tea have much positive effects in several cardiovascular disorders. Cabrera et al. [10] suggested that green tea may decrease the cardiovascular risk factor to a great extent and some forms of cancer as well as to the promotion of oral health and other physiological functions, such as antioxidant and antibacterial activities, antihypertensive effect, and body weight control. Owuor et al. [11] reported that Theaflavins (responsible for orange or orange-red colour) is present at $2 \%$ to $6 \%$ of the dry weight of solids in brewed blacktea, those are produced by the oxidative dimerization of (dihydroxy) catechin and a gallo (trihydroxy) catechin catalysed by polyphenol oxydase.

Tea polyphenols are well discussed in respect to their antioxidant belongings. Evidences have proven that the antioxidant properties of green tea relyon different catechin derivatives like epicatechin (EC), epigallocatechin gallate (EGCG) and epigallocatechin (EGC) [12] [13] [14]. Simultaneously, efficient antioxidant properties which in turn, scavenge free radicals, inhibit lipid peroxidation, and chelate metal ions have also validated in black tea [15] [16].

Scientific investigations suggest a reverse association between dietary intake of phytochemicals and certain risk factor of some human diseases [17]. Tea polyphenols are also known for their antibacterial activity. In green tea, catechins, 
particularly EGCG and ECG, have antibacterial activity against both Gram positive and Gram negative bacteria [18] [19] [20]. Wang et al. [21] reported that the green tea can prevent tooth decay by inhibiting oral bacteria. The antibacterial activity of black tea has also been reported time to time [20] [22] [23].

In view of the above, the current paper deals with a comparative interpretation of both antioxidant and antimicrobial ability of different types of packaged tea (black, green and white), which is meagre, especially in the context of Indian tea. Some secondary metabolites, related to antioxidant excellence and a series of antioxidant assays have been elucidated. Tea is such a beverage which comprising of an infusion of the processed tea leaves and is a cradle of some essential inorganic elements such as calcium $(\mathrm{Ca})$, magnesium $(\mathrm{Mg})$, iron $(\mathrm{Fr})$, zinc $(\mathrm{Zn})$, manganese (Mn) [24] [25]. Moreover, some nutrient parameters like total amino acid, total sugar, soluble protein, vitamin C, have also been considered. Antimicrobial property of the three tea types was determined against two gram positive (Bacillus subtilis MTCC 441 and Staphylococcus aureus MTCC 3160) and two gram negative (Escherichia coli MTCC 443 and Pseudomonas aeruginosa MTCC 2581) human pathogenic bacteria. All the experiments were done with standard methanol extract as organic solvents effectively diffuse through plant tissue, increase the cell wall permeability and disintegrate bonding between chlorophyll and protein molecules [26] as well as infusion with normal water of the packaged tea since the authors tried to understand the exact consumable amount of secondary metabolites and the nutrient quality to the end users with the conventional methodology.

\section{Materials and Methods}

\subsection{Tea Samples and Extraction}

Processed tea samples (Black, Green and White), obtained from National Tea Research Foundation, Tea Board of India, were used for experimental purpose. Prior to extraction, samples were made into homogeneous fine powder using blender. Methanol extraction was prepared by keeping $2 \mathrm{~g}$ of dry powder in 50 $\mathrm{ml}$ HPLC graded methanol (Merck Millipore, Germany) and gently agitating for $1 \mathrm{~h}$ by a magnetic Stirrer. Subsequently it was undergone centrifugation for 10 min at $5000 \mathrm{rpm}$ to collect the clear supernatant and the process was repeated twice. The resulting supernatant was air dried under sterilized air to avoid any loss of heat labile compounds and dissolved in $20 \mathrm{ml}$ solvent to get a stock solution of $100 \mathrm{mg} / \mathrm{ml}$ concentration. Preparation of tea infusion was done by adding potable water of $90^{\circ} \mathrm{C}[6]$ during extraction instead of methanol and other procedures remained same. All stock extract solutions were stored at $4^{\circ} \mathrm{C}$ for further use. Only fresh extract was used in the microbiological experiments.

\subsection{Determination of Some Secondary Metabolites}

\subsubsection{Phenolic Content}

Total phenolic content in the samples was determined spectrophotometrically

(Helios $\gamma$, Thermo-Fisher Corpn.) using Folin Ciocalteau reagent according to 
the method described by Singleton, Rossi [27] with slight modification. Concentration of phenolic content was calculated from a standard curve of Gallic acid, plotted absorbance at $725 \mathrm{~nm}$ against different grades.

\subsubsection{Total Tannin}

Total tannin content present in the samples was determined by the reference method of Commission [28]. Samples were mixed with equal amount of freshly prepared ferric ammonium citrate $(0.35 \%)$ and ammonium chloride $(0.8 \%)$ and absorbance was taken at $525 \mathrm{~nm}$. Tannic Acid in different concentrations was taken as standard for preparation of reference curve.

\subsubsection{Proanthocyanidin Content}

Previously reported method of Sun et al. [29] was followed for estimation of Proanthocyanidin concentration in tea samples. The absorbance of sample-vanillin-hydrochloric acid was measured at $510 \mathrm{~nm}$ in a UV-Vis Spectrophotometer. The total Proanthocyanidin content was expressed as Catechin equivalents using the reference curve, prepared plotting absorbance against Catechin concentration.

\subsubsection{Flavonoids}

Total flavonoid content in tea methanol extract and infusions were analysed following the method of Zhishen et al. [30]. Absorbance of the resultant reaction mixture was noted with the help of a spectrophotometer at $510 \mathrm{~nm}$. Quercetin was used as standard for the determination of flavonoids concentration in tea samples.

\subsection{Total Antioxidant Activity Assay}

The ability of different tea samples to scavenge ABTS and DPPH radicals was measured spectrophotometrically by standard method [31] [32] of tracing decolourization and values were calculated to compare with the Butylated hydroxyl toluene as positive control. In all, per cent inhibition was calculated following equation:

$$
\% \text { inhibition }=\left\{\frac{\text { Absorbance }_{\text {control }}-\text { Absorbance }_{\text {sample }}}{\text { Absorbance }_{\text {control }}}\right\} \times 100
$$

Scavenging ability are expressed in terms of $\mathrm{IC}_{50}$, which means, the concentration of the plant extract that's needed to scavenge $50 \%$ of the scavengers ions present and calculated by the following equation:

$$
\mathrm{IC}_{50}=\left\{\frac{\text { Perccent inhibition }}{\text { Concentration of the Sample }}\right\} \times 50
$$

\subsection{Determination of Mineral Contents}

One gram of each tea samples were dried up to constant weight and digested with $10 \mathrm{ml}$ tri-acid mixture (Perchloric acid: Sulphuric acid: Nitric acid at 9:3:1 $\mathrm{v} / \mathrm{v} / \mathrm{v}$ ratio) in a muffle furnace at $600^{\circ} \mathrm{C}$ for about $4 \mathrm{~h}$. The transparent digested residue was filtered and the volume made up to the $100 \mathrm{ml}$ volumetric flask. 
Concentration of individual mineral element from this stalk solution was determined using Flame Photometer (for $\mathrm{Na}$ and $\mathrm{K}$ estimation) (Systronix Inc.) and Atomic Absorption Spectrophotometer (for $\mathrm{Fe}, \mathrm{Ca}, \mathrm{Mg}, \mathrm{Zn}$ and $\mathrm{Mn}$ estimation) (Spectra AA240, Varian Inc.).

\subsection{Determination of Nutritional Properties}

\subsubsection{Estimation of Total Amino Acid}

Free amino acid content in the methanol extract and tea infusion was determined by ninhydrin colour reaction method [33]. Absorbance of the amino acid-ninhydrin reaction mixture at $570 \mathrm{~nm}$ was recorded with a spectrophotometer. Different concentration of Glycine solution was used as reference for the preparation of standard curve.

\subsubsection{Total Soluble Sugar}

The soluble sugar concentration was estimated using glucose as standard following the method described by [34] with slight modification. The reaction mixture was prepared by adding $4 \mathrm{ml}$ anthrone reagent $(2 \mathrm{mg} / \mathrm{ml} \mathrm{w} / \mathrm{v}$ in conc. sulphuric acid) and allowed to react at $100^{\circ} \mathrm{C}$ for $10 \mathrm{~min}$. After a rapid cooling, absorbance of resultant solution was measured spectrophotometrically at $620 \mathrm{~nm}$.

\subsubsection{Total Soluble Protein}

Soluble protein content in all studied samples was determined following the method of Bradford [35].

\subsubsection{Vitamin C Content}

The 2, 6-dichloro phenol indophenols dye titration method described by Sadasivam, Balasubramanian [36] was utilised for estimation of the total Vitamin$\mathrm{C}$ in tea samples.

\subsection{Determination of Antimicrobial Activity}

The antimicrobial property of different tea extract and infusion was examined against two gram positive (Bacillus subtilis MTCC 441 and Staphylococcus aureus MTCC 3160) and two gram negative (Escherichia coli MTCC 443 and Pseudomonas aeruginosa MTCC 2581) human pathogenic bacteria. Strains under study, freshly cultured in nutrient broth media were surface inoculated by pouring $10^{5} \mathrm{cfu}$ on culture plates containing nutrient agar medium. On it a total $200 \mu \mathrm{l}$ sample was loaded in the consecutive well made by a sterilised cork borer. The culture plates were incubated at $35^{\circ} \mathrm{C}$ in an incubator. A broad spectrum antibiotic Ampicillin was used as positive control and the respective solvent as blank tests. After $24-72 \mathrm{~h}$ the zone of inhibition was recorded for each set and photographed.

\subsection{Statistical Analysis}

All experimental data were taken in triplicate $(n=3)$ and presented the mean with standard deviations. Pearson coefficient, (two-tailed bivariate correlation 
coefficient) was employed for the parameter such as of incidence of total phenols, Proanthocyanidin, tannin, flavonoids, and per cent inhibition of free radical scavenging by DPPH and ABTS assay were considered. Similarly, correlations, if any, among the incidence of four secondary metabolites and their antimicrobial activities on four bacterial strains have also been observed. These were derived using PASW Statistics (version 18.0) software.

\section{Results}

In secondary metabolite study, total flavonoid, total phenol, tannin and Proanthocyanidin have been considered in both methanol and aqueous infusion. In all the cases, methanol extract shows higher amount than that of the aqueous extracts. In case of TF, in both extracts, green tea shows the highest performance

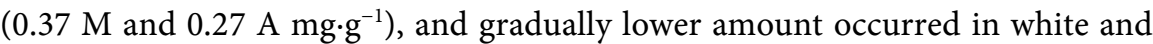
black tea. Similarly, in other secondary metabolites studied here shows the same trends, though the magnitude varied. (Figure 1(a)).

As the free radical scavenging is an indicator of antioxidant capacity of the investigated three types of tea, DPPH and ABTS assays were performed. $\mathrm{IC}_{50}$

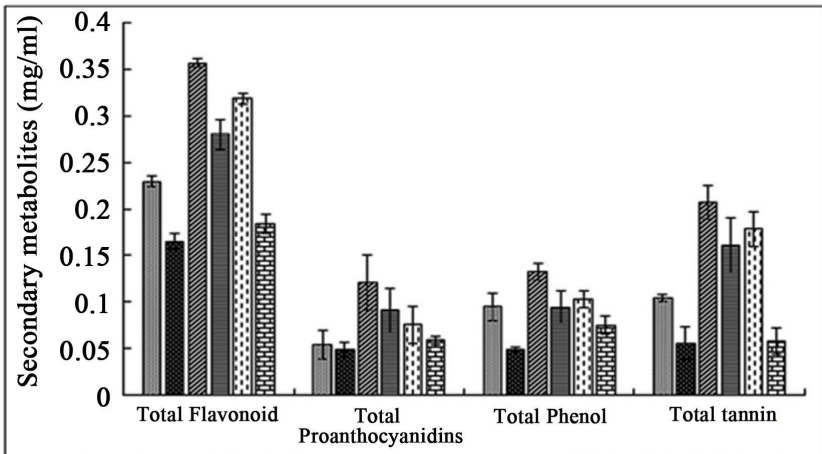

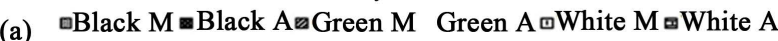
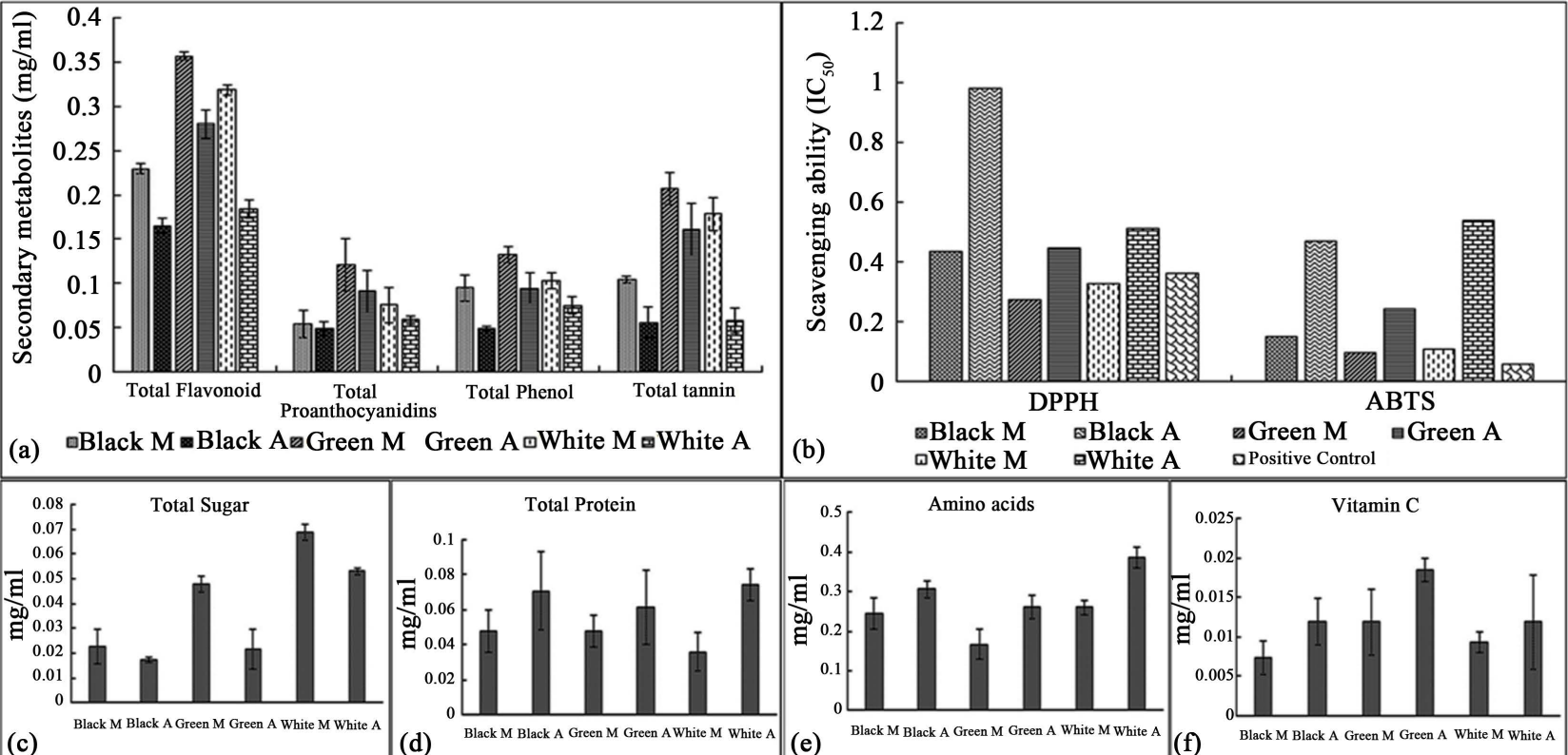

(c)

(d)

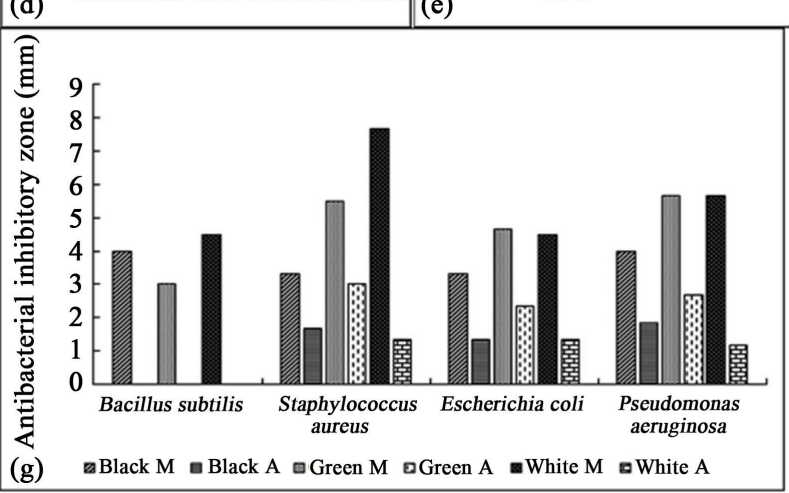

Figure 1. (a)-(g) Incidences of certain secondary metabolites, radical scavenging activity, dietary supplements and antibacterial properties of different tea extracts (M: Methanolic extract, A: Aqueous extract). 
values were considered in all the cases and usually reflected the lower value is more effective over the higher one. Hence, methanol extract always showed the lower than aqueous infusion. This assay demonstrates the highest free radical scavenging ability (both methanol and aqueous extract) in Green $(0.273$ \& $0.446)$, and followed by white $(0.326 \& 0.511)$ and black (0.436 \& 0.979 respectively) tea. Antioxidant ability has further studied in three types of tea through $\mathrm{ABTS}^{+}$radical scavenging competence. Radical scavenging ability in green tea is higher in methanol extract (0.096) and white and black tea show the consecutive lower value ( 0.109 and 0.149 respectively). The aqueous extract reveals the highest in green (0.243), black and white teas have ranked the gradual lower values (0.47 and 0.537 respectively) (Figure $1(\mathrm{~b})$ ). Positive correlation exist among the studied four secondary metabolites and radical scavenging assays with ABTS and DPPH radicals either $p \leq 0.01$ or $p \leq 0.05$ level (Table 1 ) in all three types of tea, in both methanol and water extracts as a whole.

Among the elements investigated, Potassium is consistently high in all types of tea, though black tea achieves the highest among all $\left(21.35 \mathrm{mg} \cdot \mathrm{g}^{-1}\right)$, white and green tea have scored the next lower amount respectively. Whereas, quantitative estimation of Nais highest in green tea $\left(0.55 \mathrm{mg} \cdot \mathrm{g}^{-1}\right)$, black and white tea have gradually lower amount. Calcium amount ensues consistently almost similar in three tea types. In other elements study, $\mathrm{Fe}, \mathrm{Mg}, \mathrm{Mn}$ and $\mathrm{Zn}$ show much difference in magnitude. In all cases, black tea appear in lower amount than the other two; green tea have comparatively high amount of Fe, Mg and Mn (0.166, 0.527 and $5.32 \mathrm{mg} \cdot \mathrm{g}^{-1}$ respectively), and white is the second best. Exception found only in case of $\mathrm{Zn}$, where white tea reach maximum amount $\left(0.419 \mathrm{mg} \cdot \mathrm{g}^{-1}\right)$ and green tea scores the second (Figure 2).

The property of suppressing bacterial growth of tea extracts is also highest in case of green tea (methanol extract) followed by white and black in all studied samples. Same property has been shown by green tea (aqueous infusion) too. However, among other two types, black tea has almost similar inhibitory effect

Table 1. Correlations among secondary metabolites and \% inhibition determination by DPPH and ABTS.

\begin{tabular}{ccccccccc}
\hline $\begin{array}{c}\text { Secondary } \\
\text { Metabolites }\end{array}$ & Black M & Green M & White M & Black A & Green A & White A $\begin{array}{c}\text { \% Radical } \\
\text { Scavenging }\end{array}$ \\
\hline Phenol (mg/ml) & $0.987^{* *}$ & $0.927^{*}$ & $0.968^{* *}$ & $0.945^{*}$ & $0.899^{*}$ & $0.956^{*}$ & \\
Flavonoid (mg/ml) & $0.902^{*}$ & $0.831^{*}$ & $0.903^{*}$ & $0.950^{*}$ & $0.992^{* *}$ & $0.836^{*}$ & DPPH (\% \\
$\begin{array}{c}\text { Proanthocyanidin } \\
(\mathrm{mg} / \mathrm{ml})\end{array}$ & $0.948^{*}$ & $0.846^{*}$ & $0.890^{*}$ & $0.965^{* *}$ & $0.995^{* *}$ & $0.944^{*}$ & inhibition) \\
$\begin{array}{c}\text { Tannin (mg/ml) } \\
\text { Phenol }\end{array}$ & $0.958^{*}$ & $0.878^{*}$ & $0.984^{* *}$ & $0.885^{*}$ & $0.925^{*}$ & $0.989^{* *}$ & \\
Flavonoid & $0.0996^{* *}$ & $0.936^{*}$ & $0.882^{*}$ & $0.878^{*}$ & $0.878^{*}$ & $0.928^{*}$ & \\
Proanthocynadin & $0.972^{* *}$ & $0.871^{*}$ & $0.839^{*}$ & $0.936^{* *}$ & $0.994^{* *}$ & $0.900^{*}$ & inhibition) \\
Tannin & $0.909^{*}$ & $0.879^{*}$ & $0.925^{*}$ & $0.926^{*}$ & $0.946^{*}$ & $0.979^{* *}$ & \\
\hline
\end{tabular}

$\mathbf{M}=$ methanol extract, $\mathbf{A}=$ aqueous extract. ${ }^{\star}$ Correlation is significant at $p \leq 0.05 ;{ }^{*}$ Correlation is significant at $p \leq 0.01$. 


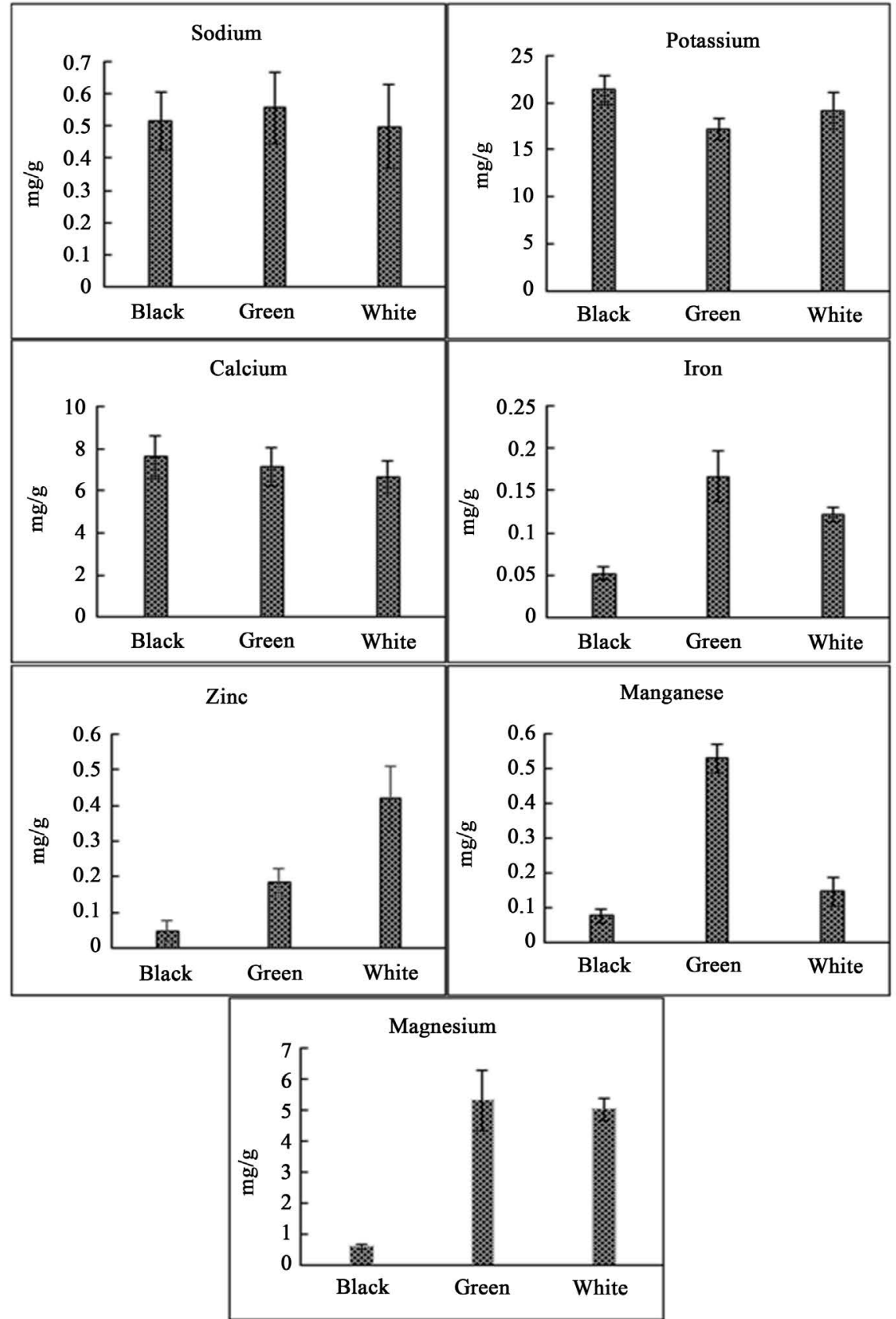

Figure 2. Elemental profile of studied tea samples.

that in white tea against $E$. coli and more than white against $S$. aureus and $P$. aeruginosa (Figure $1(\mathrm{~g})$ ). A significant positive correlation exists among Flavonoid and Tannin contents of all three type tea extracts and their microbial inhibitory effect (Table 2). Exception occurs only against B. subtilis where no inhibitory effect of aqueous infusion is being detected in all studied sets. The event of no correlation in case of $B$. subtilis is possibly due to the ineffectiveness of the studied extract against such particular strain of bacterium.

The nutritional aspects have considered here by estimating total sugar, total protein, amino acid and vitamin C. Occurrence of total sugar is higher in me- 
Table 2. Correlations among the secondary metabolites and antimicrobial activity.

\begin{tabular}{ccccc}
\hline Secondary Metabolites & $\begin{array}{c}\text { Bacillus } \\
\text { subtilis }\end{array}$ & $\begin{array}{c}\text { Staphylococcus } \\
\text { aureus }\end{array}$ & $\begin{array}{c}\text { Escherichia } \\
\text { coli }\end{array}$ & $\begin{array}{c}\text { Pseudomonas } \\
\text { aeruginosa }\end{array}$ \\
\hline Flavonoid & 0.591 & $0.847^{*}$ & $0.900^{*}$ & $0.877^{*}$ \\
Proanthocyanidin & 0.195 & 0.519 & 0.636 & 0.598 \\
Phenol & 0.625 & 0.715 & $0.878^{*}$ & $0.826^{*}$ \\
Tannin & 0.544 & $0.825^{*}$ & $0.867^{*}$ & $0.850^{*}$ \\
\hline
\end{tabular}

${ }^{\star}$ Correlation is significant at $p \leq 0.05 ;{ }^{*}$ Correlation is significant at $p \leq 0.01$.

thanol extract in all three types of tea and the highest amount in white $(0.068$ $\left.\mathrm{mg} \cdot \mathrm{ml}^{-1}\right)$, while black and green have almost in same amount(0.022 and 0.021 $\mathrm{mg} \cdot \mathrm{ml}^{-1}$ ) (Figure $1(\mathrm{c})$ ). In aqueous extract, the same trend has been observed. Total soluble protein shows in higher quantity in water infused sample of all teas. Among them, white and black tea have almost same quantities (0.074 and $\left.0.071 \mathrm{mg} \cdot \mathrm{ml}^{-1}\right)$ and comparatively less in green $\left(0.061 \mathrm{mg} \cdot \mathrm{ml}^{-1}\right)$ (Figure $1(\mathrm{~d})$ ). In organic solvent extract, the same trend has observed, i.e. black and white reproduce same result, while green shows comparatively less amount. Incidence of soluble amino acid is much higher in water extract of all tea types, among which green tea reaches top, corresponding ranks are black and white tea $(0.384,0.305$ and $0.25 \mathrm{mg} \cdot \mathrm{ml}^{-1}$ respectively). In methanol extract, the same trend has observed $\left(0.26,0.245\right.$ and $0.166 \mathrm{mg} \cdot \mathrm{ml}^{-1}$ respectively) (Figure $1(\mathrm{e})$ ). Water soluble vitamin C, is expectedly higher in aqueous infused sample than that of methanol extracts; among the three types, green tea shows the higher $\left(0.018 \mathrm{mg} \cdot \mathrm{ml}^{-1}\right)$ and similar in case of black and white teas $\left(0.012 \mathrm{mg} \cdot \mathrm{ml}^{-1}\right)$ (Figure $1(\mathrm{f})$ ). In methanol extracted sample, the amount of vitamin $\mathrm{C}$ occurs higher in green $(0.012$ $\left.\mathrm{mg} \cdot \mathrm{ml}^{-1}\right)$, then white $\left(0.009 \mathrm{mg} \cdot \mathrm{ml}^{-1}\right)$ and black tea $\left(0.007 \mathrm{mg} \cdot \mathrm{ml}^{-1}\right)$.

\section{Discussion}

Tea is widely popular consumable beverage across the globe and its nutritional value is being considered as a potential supplement of various nutritional qualities. Hence, information about its dietary assessment is of practical requisite both for tea promoter and the end users, as well. In the present work, some of these have been considered.

Several bioactive secondary metabolites contribute tea antioxidant property and thus, tea is a prospective source of antioxidant supplement. The positive effects of tea polyphenols can be attributed to the antioxidant properties. Besides, antimutagenic, anticarcinogenic, hypocholesterolomic, antibacterial, and antiallergenic effects of tea have also been reported [37]. Processing methods and different agronomic practices have altered the incidence of these bioactive molecules much [38]. The present result revealed that green tea, both in methanol and aqueous extracts have more secondary metabolites (total phenol, flavonoids, tannin and Proanthocyanidin). White tea obtained from rudimentary leaf buds, and only after sun drying is allowed before packaging. Green tea undergoes only 
withering, pan frying, and drying. Fermentation processes only offered to black orthodox tea. Treating of tea leaves consequences in differences in phenolic compound and antioxidant aptitude of different types of tea [39]. Hence, green tea, being less processed of mature tea leaves, contain higher amount of antioxidant related secondary metabolites, than that of the black one. White tea, prepared from rudimentary leaf buds, also shows higher value than black as white tea also a product of minimum processing technique. Kosińska, Andlauer [39] commented that more processed the tea, the lower its antioxidant capacity. Antioxidant activity has estimated using DPPH and ABTS radical scavenging assay. In both radical scavenging assays, lower $\mathrm{IC}_{50}$ values have been obtained in green tea (i.e. low concentration of sample needed for scavenging free radicals by $50 \%) . \mathrm{IC}_{50}$ is higher in black tea proved less free radical scavenging ability. This is well accordance with the obtained results for occurrence of antioxidant secondary metabolites. Earlier reports have shown that green tea has stronger antioxidant properties than black tea [40] [41] [42]. The main chemical constituents of green tea are catechin of EGCG, EGC, ECG, and EC [43] [44]. The potent antioxidant activities of catechin in green tea are due to their three adjacent hydroxyl $(\mathrm{OH})$ groups on the B-ring as in EGCG, GCG, EGC, and GC which are more effective in scavenging free radicals than the two adjacent $\mathrm{OH}$ groups as in ECG, CG, and EC [44]. The content of EGCG and EGC in green tea is much higher than in black tea [23]. Although green tea has higher TPC, free radical scavenging activity, and ferric reducing power, its ferrous ion chelating ability is poorer than black tea [40] [41].

Total sugar in organic solvent, white tea exhibit the highest, gradually lower in green and black tea. This is due to the fermentation during tea processing. Green tea undergoes a less fermentation and black tea is being offered more. Water soluble protein occurred per gram of all three types of tea is almost same, though in black and white teas, it is slightly higher. Free amino acid in all three types of tea occurred more in aqueous infusion as amino acid is readily dissolve in water. Green tea showing lower amount than white and black tea. Amino acids in tea have dual nutritional roles for essential amino acids and the pharmacological effects of theanine and $\gamma$-aminobutyric acid (GABA) [45]. As already known L-theanine, uniquely found in tea and accounts for over $50 \%$ of total amino acid, can decrease norepinephrine and serotonin levels in the brain, lower blood pressure and produce neuroprotective and cognitive-enhancing actions [46]. On the other hand, GABA rich teas are reported to reduce blood pressure in rats [47]. Moreover, amino acids take part in the biosynthesis of polyphenols and alkaloids [48]. Water soluble vitamin C attains the leading position in green tea; while black and white exhibit the same magnitude. Vitamin $\mathrm{C}$ has a multifaceted beneficiary contribution for well-being, especially antioxidant ability.

The results of present study on antimicrobial activity is in congruence with earlier works [22] [42] where green tea had higher antimicrobial activity than black or white teas, as fermentation process during tea manufacturing bears negative regulatory role on bactericidal properties [23] [49]. It is well known that 
green tea leaf polyphenols especially catechins play an important role in its bactericidal properties [50] [51] and during fermentation these molecules are oxidised to other type which are responsible for colour development primarily. As a result, antibacterial property is slightly reduced. Although white tea is often called as non-fermented tea, still oxidising enzymes here remain active for colour development and polyphenols undergo slight oxidation, as enzymes inactivation are not done before withering of white teas [52] [53]. Higher inhibitory effect of black tea in some cases might be due to their considerable amount of tannin content. The significant positive correlation of bacterial growth inhibition with tannin and flavonoid were found in this study. Similar incidences were described earlier where role of tannin as an antibacterial agent have clearly elucidated [54] [55] [56] [57] [58]. In addition to different flavones, polyphenol compounds and phenolic acids are also evidently responsible for antibacterial properties as stated earlier [59] [60].

Sodium content is higher in green tea, though black and white tea show almost same amount which are nearer to the green tea. Manufacturing process, does not interfere greatly in $\mathrm{Na}$ amount in black and green tea, only leaf maturity differs as, white tea prepared from only rudimentary leaf. Na is essential for maintaining fluid and acid-base balance. Potassium (K) content shows the reverse trend, green contains the lowest amount and black shows the highest amount. Both $\mathrm{Na}$ and $\mathrm{K}$ take active part in different metabolic activities. $\mathrm{Na}^{+}$and $\mathrm{K}^{+}$ion have some interchangeable characteristics. It has been observed in many cases that, during $\mathrm{K}^{+}$deficiency, plants respond completely to $\mathrm{Na}^{+}$ion [61]. Basically, both perform almost same body functions, such as muscle contraction and fluid balance, but in some reverse manner. For example, sodium draws fluid outward to cells, increasing blood pressure, while potassium allurements inward direction of fluid, decreasing blood pressure. Additionally, sodium intake can affect potassium excretion from the body, just as potassium intake can affect sodium excretion. High $\mathrm{Na}$ and low $\mathrm{K}$ diet can adversely affect towards hypertension. The hypotensive consequence of high $\mathrm{K}$ intake is deactivated by the supplementary high source of $\mathrm{Na}$ [62]. An increased intake of one mineral will result in an increased excretion of the other mineral [63]. Ca amount shows leading amount in black tea, green and white ranked in consecutive lower positions, though the differences are minute. Ono et al. [64] reported that Ca rich dietary component is responsible for preventing elevated hypertension caused by excess $\mathrm{Na}$ accumulation. Calcium is essential for vasoconstriction and dilation, muscle function, nerve communication, intracellular signalling and hormonal excretion, though less than $1 \%$ of total body $\mathrm{Ca}$ is needed to support these critical metabolic functions, remaining $99 \%$ supply is stored in the bones and teeth maintaining their structure and function [65]. In present experiments, minerals, like, $\mathrm{Fe}, \mathrm{Mg}$ and $\mathrm{Mn}$, all occurred in higher amount in green tea, moderate in white and lowest in black tea, except $\mathrm{Zn}$, which attained highest in white tea. $\mathrm{Zn}$ attentiveness in the diet plays a vital role in the parameter of systolic blood pressure and considered as a critical nutrient for maintenance of anti-oxidative events 
[66]. Zinc is also essential in several metabolic pathways in humans and deficiency can lead to loss of hunger, growth obstruction, skin changes and immunological aberrations [67]. White tea might be considered as beneficial over other two types in this respect. Green tea is superior in $\mathrm{Fe}, \mathrm{Mn}$ and $\mathrm{Mg}$ content with respect to other two types. Manganese is a compulsion for suitable function of several enzymes and an essential micro-nutrient for proper functioning of brain, nervous system, and normal bone growth [68]. Ipeaiyeda, Dawodu [69] opined that tea is the potential source of dietary elements and the amount would not be perilous for health except Mn since it percolates out from tea is above the WHO permissible limit $(0.5 \mathrm{~g} / \mathrm{L}$; [70]). They also reported that chelating activity of polyphenols and caffeine by manganese is high when compared with the chelating activities for $\mathrm{Fe}, \mathrm{Cu}$ and $\mathrm{Zn}$. Jeszka-Skowron et al. [71] also reported the highest amount of $\mathrm{Mn}$ in green tea infusion in comparison to black and white teas. Magnesium being the central component of chlorophyll, green tea holds its higher value over the other two types as green tea undergoes without fermentation. Experimental proof revealed that the highest levels of catechins, total polyphenols have led to increased antioxidant property in green tea and black tea contained high levels of theaflavins and thearubigins, responsible for high antioxidant potentiality [9]. They also reported that the conversion of catechins (present in Green tea) to theaflavins during black tea processing has no effect in free radical scavenging potency.

From this study, it is evident that though green tea has enough superior health-benefit qualities in terms of higher phenolic compounds and antioxidant ability, but it contains positive $\mathrm{Na}^{+} / \mathrm{K}^{+}$ratio which is not desirable in case of cardio-vascular disorder. It is considered that higher levels of $\mathrm{Na}^{+} / \mathrm{K}^{+}$in the body are the most important determinants of health status including arterial hypertension. Amount of $\mathrm{K}$ and $\mathrm{Ca}$ are higher in black tea and white tea has more $\mathrm{K}$ than green. Present work shows that incidence of relatively high Mnin green tea and normally which infuses out from tea is above the WHO permissible limit, thus excess of Mn content in green might be supersede the acceptable limit. Though manganese plays an important role for development, metabolism, and the antioxidant system of human body, but excess may lead to neurodegenerative disorder, similar to Parkinson's disease [72]. Black and white teas show some advantage in these regard, though they are to some extent inferior to green tea in respect to antioxidant quality.

\section{Conclusion}

The present work focused on the dietary importance of black, green and white teas and their comparative assessment. Results on antioxidant parameters (occurrence of bioactive secondary metabolites) pointed out towards the gradation of advantage like Green $>$ White > Black tea. Incidence of essential metal ions, green tea shows higher amount than those of other types, whereas black tea holds higher position in having $\mathrm{K}$ and $\mathrm{Ca}$. Low $\mathrm{Na}$ and high $\mathrm{K}$ amount is preferable for well-being state. Higher Mn content (in green tea) might be considered 
to be some extent disadvantageous in tea infusion normally; Mn percolates out supersede the WHO recommended amount. Though, both antibacterial and antioxidant ability are in leading position to green tea; black and white tea also have considerable ability to these activities as a whole. Consumption of different types of tea mainly relies on the individual perception and taste; black and white teas are not at all inferior to green tea in a great extent.

\section{Acknowledgements}

Authors deeply acknowledge Dr. N. C. Karmakar, Barasat Government College for his help in flame photometric study and Ms. Adrita Banerjee, Department of Botany, University of Kalyani for helping to get bacterial pure culture.

\section{Conflict of Interest}

Authors do not have any conflict of interest in publication of this manuscript.

\section{References}

[1] Kuroda, Y. (1990) Antimutagenesis Studies in Japan. In: Kuroda, Y., Shankel, D.M., et al., Eds., Antimutagenesis and Anticarcinogenesis Mechanisms II, Springer, Berlin, 1-22. https://doi.org/10.1007/978-1-4615-9561-8_1

[2] Mcfarlane, A. and Mcfarlane, I. (2004) The Empire of Tea. The Overlook Press, New York.

[3] Chang, H.T. and Bartholomew, B. (1984) Camellias. Timbcr Press, Portland, Oregon, London, 137-153.

[4] Ming, T. and Zhang, W. (1995) The Evolution and Distribution of Genus Camellia. Acta Botanica Yunnanica, 18, 1-13.

[5] Ta, C.H. and Hongda, Z. (1981) A Taxonomy of the Genus Camelia. Editorial Staff of the Journal of Sun Yatsen University.

[6] Venditti, E., Bacchetti, T., Tiano, L., Carloni, P., Greci, L. and Damiani, E. (2010) Hot vs. Cold Water Steeping of Different Teas: Do They Affect Antioxidant Activity? Food Chemistry, 119, 1597-1604.

https://doi.org/10.1016/j.foodchem.2009.09.049

[7] Hilal, Y. and Engelhardt, U. (2007) Characterisation of White Tea-Comparison to Green and Black Tea. Journal für Verbraucherschutz und Lebensmittelsicherheit, 2, 414-421.

[8] Sajilata, M., Bajaj, P.R. and Singhal, R. (2008) Tea Polyphenols as Nutraceuticals. Comprehensive Reviews in Food Science and Food Safety, 7, 229-254.

https://doi.org/10.1111/j.1541-4337.2008.00043.x

[9] Karori, S., Wachira, F., Wanyoko, J. and Ngure, R. (2007) Antioxidant Capacity of Different Types of Tea Products. African Journal of Biotechnology, 6, 2287-2296. https://doi.org/10.5897/AJB2007.000-2358

[10] Cabrera, C., Artacho, R. and Giménez, R. (2006) Beneficial Effects of Green Tea-A Review. Journal of the American College of Nutrition, 25, 79-99. https://doi.org/10.1080/07315724.2006.10719518

[11] Owuor, P.O., Obanda, M., Nyirenda, H.E., Mphangwe, N.I., Wright, L.P. and Apostolides, Z. (2006) The Relationship between Some Chemical Parameters and Sensory Evaluations for Plain Black Tea (Camellia sinensis) Produced in Kenya and Comparison with Similar Teas from Malawi and South Africa. Food Chemistry, 97, 
644-653. https://doi.org/10.1016/j.foodchem.2005.04.027

[12] Kondo, K., Kurihara, M., Miyata, N., Suzuki, T. and Toyoda, M. (1999) Scavenging Mechanisms of (-)-Epigallocatechin Gallate and (-)-Epicatechin Gallate on Peroxyl Radicals and Formation of Superoxide during the Inhibitory Action. Free Radical Biology and Medicine, 27, 855-863. https://doi.org/10.1016/S0891-5849(99)00133-1

[13] Farhoosh, R., Golmovahhed, G.A. and Khodaparast, M.H. (2007) Antioxidant Activity of Various Extracts of Old Tea Leaves and Black Tea Wastes (Camellia sinensis L.). Food Chemistry, 100, 231-236. https://doi.org/10.1016/j.foodchem.2005.09.046

[14] Horžić, D., Komes, D., Belščak, A., Ganić, K.K., Iveković, D. and Karlović, D. (2009) The Composition of Polyphenols and Methylxanthines in Teas and Herbal Infusions. Food Chemistry, 115, 441-448. https://doi.org/10.1016/j.foodchem.2008.12.022

[15] Wiseman, S.A., Balentine, D.A. and Frei, B. (1997) Antioxidants in Tea. Critical Reviews in Food Science \& Nutrition, 37, 705-718. https://doi.org/10.1080/10408399709527798

[16] Łuczaj, W. and Skrzydlewska, E. (2005) Antioxidative Properties of Black Tea. Preventive Medicine, 40, 910-918. https://doi.org/10.1016/j.ypmed.2004.10.014

[17] Bushman, J.L. (1998) Green Tea and Cancer in Humans: A Review of the Literature. Nutrition and Cancer, 31, 151-159. https://doi.org/10.1080/01635589809514697

[18] Toda, M., Okubo, S., Ikigai, H. and Shimamura, T. (1990) Antibacterial and Anti-Hemolysin Activities of Tea Catechins and Their Structural Relatives. Japanese Journal of Bacteriology, 45, 561-566. https://doi.org/10.3412/jsb.45.561

[19] Hamilton-Miller, J. (1995) Antimicrobial Properties of Tea (Camellia sinensis L.). Antimicrobial Agents and Chemotherapy, 39, 2375-2377.

https://doi.org/10.1128/aac.39.11.2375

[20] Bancirova, M. (2010) Comparison of the Antioxidant Capacity and the Antimicrobial Activity of Black and Green Tea. Food Research International, 43, 13791382. https://doi.org/10.1016/j.foodres.2010.04.020

[21] Wang, H., Provan, G.J. and Helliwell, K. (2000) Tea Flavonoids: Their Functions, Utilisation and Analysis. Trends in Food Science \& Technology, 11, 152-160. https://doi.org/10.1016/S0924-2244(00)00061-3

[22] Tiwari, R., Bharti, S., Kaur, H., Dikshit, R. and Hoondal, G. (2005) Synergistic Antimicrobial Activity of Tea \& Antibiotics. Indian Journal of Medical Research, 122, 80.

[23] Almajano, M.P., Carbo, R., Jiménez, J.A.L. and Gordon, M.H. (2008) Antioxidant and Antimicrobial Activities of Tea Infusions. Food Chemistry, 108, 55-63. https://doi.org/10.1016/j.foodchem.2007.10.040

[24] Turcot, I., Stintzi, A., Xu, J. and Raymond, K.N. (2000) Fast Biological Iron Chelators: Kinetics of Iron Removal from Human Diferric Transferrin by Multidentate Hydroxypyridonates. Journal of Biological Inorganic Chemistry, 5, 634-641. https://doi.org/10.1007/s007750000149

[25] The Tea Council (2004). http://www.teacouncil.co.uk

[26] Hosikian, A., Lim, S., Halim, R. and Danquah, M.K. (2010) Chlorophyll Extraction from Microalgae: A Review on the Process Engineering Aspects. International Journal of Chemical Engineering, 2010, Article ID: 391632. https://doi.org/10.1155/2010/391632

[27] Singleton, V. and Rossi, J.A. (1965) Colorimetry of Total Phenolics with Phosphomolybdic-Phosphotungstic Acid Reagents. American Journal of Enology and Viti- 
culture, 16, 144-158.

[28] Commission, E. (2000) Procédures de prises en charge de cereals par les organismesd'interventionainsique les methodesd'analyses pour la determination de la qualité. Journal Officiel des Communautés Européennes, 824.

[29] Sun, B., Ricardo-da-Silva, J.M. and Spranger, I. (1998) Critical Factors of Vanillin Assay for Catechins and Proanthocyanidins. Journal of Agricultural and Food Chemistry, 46, 4267-4274. https://doi.org/10.1021/jf980366j

[30] Jia, Z., Tang, M. and Wu, J. (1999) The Determination of Flavonoid Contents in Mulberry and Their Scavenging Effects on Superoxide Radicals. Food Chemistry, 64, 555-559. https://doi.org/10.1016/S0308-8146(98)00102-2

[31] Re, R., Pellegrini, N., Proteggente, A., Pannala, A., Yang, M. and Rice-Evans, C. (1999) Antioxidant Activity Applying an Improved ABTS Radical Cation Decolorization Assay. Free radical Biology and Medicine, 26, 1231-1237. https://doi.org/10.1016/S0891-5849(98)00315-3

[32] Blois, M.S. (1958) Antioxidant Determinations by the Use of a Stable Free Radical. Nature, 181, 1199-1200.

[33] Moore, S. and Stein, W.H. (1954) A Modified Ninhydrin Reagent for the Photometric Determination of Amino Acids and Related Compounds. Journal of Biological Chemistry, 211, 907-913.

[34] Fu, B., Xie, M., Nie, S., Zhou, P. and Wang, Y. (2001) Determination of the Contents of Polysaccharides in Tea. Chinese Journal of Food Science, 22, 69-73.

[35] Bradford, M.M. (1976) A Rapid and Sensitive Method for the Quantitation of Microgram Quantities of Protein Utilizing the Principle of Protein-Dye Binding. Analytical Biochemistry, 72, 248-254. https://doi.org/10.1016/0003-2697(76)90527-3

[36] Sadasivam, S. and Balasubramanian, T. (1987) Practical Manual in Biochemistry. Tamil Nadu Agricultural University, Coimbatore, India, 14.

[37] Cooper, R. (2012) Green Tea and Theanine: Health Benefits. International Journal of Food Sciences and Nutrition, 63, 90-97. https://doi.org/10.3109/09637486.2011.629180

[38] Ku, K.M., Choi, J.N., Kim, J., Kim, J.K., Yoo, L.G., Lee, S.J., Hong, Y-S. and Lee, C.H. (2009) Metabolomics Analysis Reveals the Compositional Differences of Shade Grown Tea (Camellia sinensis L.). Journal of Agricultural and Food Chemistry, 58, 418-426. https://doi.org/10.1021/jf902929h

[39] Kosińska, A. and Andlauer, W. (2014) Antioxidant Capacity of Tea: Effect of Processing and Storage. In: Preedy, V., Ed., Processing and Impact on Antioxidants in Beverages, Elsevier, Amsterdam, 109-120.

[40] Chan, E., Lim, Y. and Chew, Y. (2007) Antioxidant Activity of Camellia sinensis Leaves and Tea from a Lowland Plantation in Malaysia. Food Chemistry, 102, 12141222. https://doi.org/10.1016/j.foodchem.2006.07.009

[41] Chan, E., Lim, Y., Chong, K., Tan, J. and Wong, S. (2010) Antioxidant Properties of Tropical and Temperate Herbal Teas. Journal of Food Composition and Analysis, 23, 185-189. https://doi.org/10.1016/j.jfca.2009.10.002

[42] Chan, E.W., Soh, E.Y., Tie, P.P. and Law, Y.P. (2011) Antioxidant and Antibacterial Properties of Green, Black, and Herbal Teas of Camellia sinensis. Pharmacognosy Research, 3, 266-272. https://doi.org/10.4103/0974-8490.89748

[43] Chopade, V., Phatak, A., Upaganlawar, A. and Tankar, A. (2008) Green Tea (Camellia sinensis): Chemistry, Traditional, Medicinal Uses and Its Pharmacological Activities-A Review. Pharmacognosy Reviews, 2, 157.

[44] Sharma, A., Wang, R., Zhou, W. and Shahidi, F. (2010) Functional Foods from 
Green Tea. In: Shahidi, F., Ed., Functional Foods of the East, CRC Press, Boca Raton, 173-195. https://doi.org/10.1201/b10264-9

[45] Bi, W., He, C., Ma, Y., Shen, J., Zhang, L.H., Peng, Y. and Xiao, P. (2016) Investigation of Free Amino Acid, Total Phenolics, Antioxidant Activity and Purine Alkaloids to Assess the Health Properties of Non-Camellia Tea. Acta Pharmaceutica Sinica $B, 6,170-181$. https://doi.org/10.1016/j.apsb.2015.11.003

[46] Nathan, P.J., Lu, K., Gray, M. and Oliver, C. (2006) The Neuropharmacology of L-Theanine (N-Ethyl-L-Glutamine) a Possible Neuroprotective and Cognitive Enhancing Agent. Journal of Herbal Pharmacotherapy, 6, 21-30.

[47] Abe, Y., Umemura, S., Sugimoto, K.-I., Hirawa, N., Kato, Y., Yokoyama, N., Yokoyama, T., Iwai, J. and Ishii, M. (1995) Effect of Green Tea Rich in $\gamma$-Aminobutyric Acid on Blood Pressure of Dahl Salt-Sensitive Rats. American Journal of Hypertension, 8, 74-79. https://doi.org/10.1016/0895-7061(94)00141-W

[48] Dewick, P.M. (2002) Medicinal Natural Products: A Biosynthetic Approach. John Wiley \& Sons, Hoboken.

[49] Toda, M., Okubo, S., Hiyoshi, R. and Shimamura, T. (1989) The Bactericidal Activity of Tea and Coffee. Letters in Applied Microbiology, 8, 123-125.

https://doi.org/10.1111/j.1472-765X.1989.tb00255.x

[50] Sharangi, A. (2009) Medicinal and Therapeutic Potentialities of Tea (Camellia sinensis L.)-A Review. Food Research International, 42, 529-535. https://doi.org/10.1016/j.foodres.2009.01.007

[51] Gopal, J., Muthu, M., Paul, D., Kim, D-H. and Chun, S. (2016) Bactericidal Activity of Green Tea Extracts: The Importance of Catechin Containing Nano Particles. Scientific Reports, 6, Article No. 19710. https://doi.org/10.1038/srep19710

[52] Jiang, H.-Y. (2009) White Tea: Its Manufacture, Chemistry, and Health Effects. In: Ho, C.-T., Lin, J.-K. and Shahidi, F., Eds., Chemistry and Health-Promoting Properties, CRC Press, Boca Raton, 17-29.

[53] Carloni, P., Tiano, L., Padella, L., Bacchetti, T., Customu, C., Kay, A. and Damiani, E. (2013) Antioxidant Activity of White, Green and Black Tea Obtained from the Same Tea Cultivar. Food Research International, 53, 900-908. https://doi.org/10.1016/j.foodres.2012.07.057

[54] Turkmen, N., Velioglu, Y.S., Sari, F. and Polat, G. (2007) Effect of Extraction Conditions on Measured Total Polyphenol Contents and Antioxidant and Antibacterial Activities of Black Tea. Molecules, 12, 484-496. https://doi.org/10.3390/12030484

[55] Amarowicz, R., Dykes, G.A. and Pegg, R.B. (2008) Antibacterial Activity of Tannin Constituents from Phaseolus vulgaris, Fagoypyrum esculentum, Corylus avellana and Juglans nigra. Fitoterapia, 79, 217-219. https://doi.org/10.1016/j.fitote.2007.11.019

[56] Min, B., Pinchak, W., Merkel, R., Walker, S., Tomita, G. and Anderson, R. (2008) Comparative Antimicrobial Activity of Tannin Extracts from Perennial Plants on Mastitis Pathogens. Scientific Research and Essay, 3, 066-073.

[57] Doss, A., Mubarack, H.M. and Dhanabalan, R. (2009) Antibacterial Activity of Tannins from the Leaves of Solanum trilobatum Linn. Indian Journal of Science and Technology, 2, 41-43.

[58] Scalbert, A. (1991) Antimicrobial Properties of Tannins. Phytochemistry, 30, 38753883. https://doi.org/10.1016/0031-9422(91)83426-L

[59] Shimamura, T., Toda, M., Okuba, S. and Hara, Y. (1990) Antibacterial and Antihaemolytic Activities of Tea Catechins and Their Structural Relatives. Nippon-Saikingaku-Zasshi, 69, 1126-1134. 
[60] Yam, T., Shah, S. and Hamilton-Miller, J. (1997) Microbiological Activity of Whole and Fractionated Crude Extracts of Tea (Camellia sinensis), and of Tea Components. FEMS Microbiology Letters, 152, 169-174. https://doi.org/10.1111/j.1574-6968.1997.tb10424.x

[61] Subbarao, G., Ito, O., Berry, W. and Wheeler, R. (2003) Sodium-A Functional Plant Nutrient. Critical Reviews in Plant Sciences, 22, 391-416. https://doi.org/10.1080/07352680390243495

[62] Rębacz-Maron, E., Baranowska-Bosiacka, I., Gutowska, I. and Chlubek, D. (2013) Blood Pressure and Levels of $\mathrm{Fe}, \mathrm{Ca}, \mathrm{Mg}, \mathrm{Zn}, \mathrm{Cu}, \mathrm{Na}$ and $\mathrm{K}$ in the Hair of Young Bantu Men from Tanzania. Biological Trace Element Research, 151, 350-359. https://doi.org/10.1007/s12011-012-9578-3

[63] Morris Jr., R.C., Schmidlin, O., Frassetto, L.A. and Sebastian, A. (2006) Relationship and Interaction between Sodium and Potassium. Journal of the American College of Nutrition, 25, 262S-270S.

[64] Ono, A., Ando, K. and Fujita, T. (1994) High-Calcium Diet Prevents Salt-Induced Hypertension and Impairment of Renal Hemodynamics in Young Spontaneously Hypertensive Rats. Journal of Cardiovascular Pharmacology, 23, 624-628. https://doi.org/10.1097/00005344-199404000-00015

[65] USA Food and Nutrition Board (2010) Review of Dietary Reference Intakes for Vitamin D and Calcium. Institute of Medicine, National Academy Press, Washington DC.

[66] Dimitrova, A., Strashimirov, D., Betova, T., Russeva, A. and Alexandrova, M. (2008) Zinc Content in the Diet Affects the Activity of $\mathrm{Cu} / \mathrm{ZnSOD}$, Lipid Peroxidation and Lipid Profile of Spontaneously Hypertensive Rats. Acta Biologica Hungarica, 59, 305-314. https://doi.org/10.1556/ABiol.59.2008.3.4

[67] Reddy, K.J., Kumar, J.R., Ramachandraiah, C., Thriveni, T. and Reddy, A.V. (2007) Spectrophotometric Determination of Zinc in Foods Using N-Ethyl-3-Carbazolecarboxaldehyde-3-Thiosemicarbazone: Evaluation of a New Analytical Reagent. Food Chemistry, 101, 585-591. https://doi.org/10.1016/j.foodchem.2006.02.018

[68] Liang, P., Sang, H. and Sun, Z. (2006) Cloud Point Extraction and Graphite Furnace Atomic Absorption Spectrometry Determination of Manganese(II) and Iron(III) in Water Samples. Journal of Colloid and Interface Science, 304, 486-490. https://doi.org/10.1016/j.jcis.2006.09.006

[69] Ipeaiyeda, A. and Dawodu, M. (2011) Leaching of Manganese, Iron, Copper and Zinc from Tea (Camellia sinensis) in Tea Mugs. Electronic Journal of Environmental, Agricultural and Food Chemistry, 10, 2240-2247.

[70] World Health Organization (1993) Guidelines for Drinking-Water Quality, 1 Recommendations. 2nd Edition, WHO, Geneva.

[71] Jeszka-Skowron, M., Krawczyk, M. and Zgoła-Grześkowiak, A. (2015) Determination of Antioxidant Activity, Rutin, Quercetin, Phenolic Acids and Trace Elements in Tea Infusions: Influence of Citric Acid Addition on Extraction of Metals. Journal of Food Composition and Analysis, 40, 70-77. https://doi.org/10.1016/j.jfca.2014.12.015

[72] Avila, D.S., Puntel, R.L. and Aschner, M. (2013) Manganese in Health and Disease. In: Sigel, A., Sigel, H. and Sigel, R.K.O., Eds., Interrelations between Essential Metal Ions and Human Diseases, Springer, Netherlands, 199-227. https://doi.org/10.1007/978-94-007-7500-8_7 
Submit or recommend next manuscript to SCIRP and we will provide best service for you:

Accepting pre-submission inquiries through Email, Facebook, LinkedIn, Twitter, etc. A wide selection of journals (inclusive of 9 subjects, more than 200 journals)

Providing 24-hour high-quality service

User-friendly online submission system

Fair and swift peer-review system

Efficient typesetting and proofreading procedure

Display of the result of downloads and visits, as well as the number of cited articles Maximum dissemination of your research work

Submit your manuscript at: http://papersubmission.scirp.org/

Or contact ajps@scirp.org 